\title{
Speciation and Mobility of Lead, Chromium and Zinc in Soils of Abis Region, Egypt
}

\author{
${ }^{1}$ Allafi, H.A.A., ${ }^{2}$ M.G.Nasseem, ${ }^{3}$ I.M. Morsy, ${ }^{4}$ M.A.Husein, and ${ }^{5}$ H.AbdElfatah \\ ${ }^{1}$ Center of Technology and Development Research, Tripoli, Libya \\ ${ }^{2,4,5}$ Soil and Agricultural Chemistry Department, Faculty of Agriculture, Saba Basha, \\ Alexandria, Egypt \\ ${ }^{3}$ Soil Salinity Laboratory, Institute of Soil, Water \&Environment, Agriculture Research \\ Center, Alexandria, Egypt
}

\begin{abstract}
This study describes the chemical speciation of $\mathrm{Pb}, \mathrm{Cr}$ and $\mathrm{Zn}$ in soils of Abis area in Egypt. The studied area is located at the North Western part of the Nile Delta, which represents soils developed from lacustreine deposits at Abis region south of Mariut Lake and covers about 40000 fed. Total 41 top soil samples $(0-35 \mathrm{~cm})$ were collected from the area for analysis. The total contents and fractions of $\mathrm{Pb}, \mathrm{Cr}$, and $\mathrm{Zn}$ were determined, and the mobility factor and potential mobility were calculated. Small amounts of $\mathrm{Pb}, \mathrm{Cr}$, and $\mathrm{Zn}$ retrieved from the soluble and exchangeable phases, the readily available for biogeochemical cycles in the ecosystem. Low quantities of $\mathrm{Pb}, \mathrm{Cr}$ and $\mathrm{Zn}$ could be available to plants. $\mathrm{Zn}$ is present in negligible amounts lower than those of $\mathrm{Pb}$ or $\mathrm{Cr}$. The results also indicate that most of the metals have high abundance in residual fraction indicating lithogenic origin and low bioavailability of metals in the studied soil. The values of average mobility factor for $\mathrm{Pb}, \mathrm{Cr}$ and $\mathrm{Zn}$ in the soils of Abis area were 7.31, 6.74 and $0.51 \%$, respectively which is less than $10 \%$. Therefore, these elements are highly stable in soil. The average potential mobility of $\mathrm{Pb}, \mathrm{Cr}$ and $\mathrm{Zn}$ were $15.05 \%$. $34.79 \%$ and $8.25 \%$ respectively. The $\mathrm{Zn}$ had the least average potential mobility $(8.25 \%)$. The order of average potential mobility of metals soils agrees with the percentage reduction in concentration of residual heavy metal.
\end{abstract}

Keywords: Lead, chromium, zinc, chemical speciation, mobility, potential mobility

\section{INTRODUCTION}

Soils are the reservoir for many harmful constituents, (elemental and biological), including heavy metals. Total elemental content of soils is useful for many geochemical applications but often the speciation of these metals is more of an interest agriculturally in terms of what is biologically extractable (Cottenie et al., 1980). Speciation is defined as the identification and quantification of the different, defined species, forms, or phases in which an element occurs (Tack and Verloo, 1995) and is essentially a function of the mineralogy and chemistry of the soil sample examined (Tessier et al., 1979). Quantification is typically done using chemical solutions of varying but specific strengths and reactivity to release metals from the different fractions of the examined soil (Ryan et al., 2008). In terms of bioavailability, various species of metals are more biologically available in the ecosystem (Nelson and Donkin, 1985). Bioavailability and the mobility of metals are also related to each other, then higher concentration of mobile toxic metals in the soil which increases the potential for plant uptake, and animal/human consumption (Ratuzny et al., 2009). Heavy metals are included in soil minerals as well as bound to different phases of soil particles by a variety of mechanisms. Moreover, soil properties such as contents of organic matter, carbonates and oxides influence the heavy metal mobility (Kabata-Pendias and Pendias, 2001). It is widely recognized 
that to assess the environmental impact of soil pollution, the determination of the metal speciation will give more information about the potential for release of contaminants and further derived processes of migration and toxicity (Usero et al., 1998). Therefore, in geo-environmental studies of risk assessment, chemical partitioning among the various geochemical phases is more useful than measurements of total heavy metals contents (Quevauviller et al., 1996). There is no information available in the literature on heavy metals speciation, mobility, availability and toxicity in soils of Abis region in Egypt. Herein, the objectives of this study were aimed at determining the speciation and mobility of $\mathrm{Pb}, \mathrm{Cr}$ and $\mathrm{Zn}$ metals in the top soil of this area.

\section{MATERIAL AND METHODS Site description and soil samples}

The studied area is located between $31^{\circ} 00^{\prime}$ to $31^{\circ} 30^{\prime} \mathrm{N}$ and $29^{\circ} 30^{\prime}$ to $30^{\circ}$ $30^{\prime} \mathrm{E}$ at the north western delta fringes south of Mariut Lake which named Abis (Map 1). It covers parts of Alexandria and El-Behira Governorates with total area about 40000 Fed. Forty one surface $(0-35 \mathrm{~cm})$ soil samples representing the studied area were taken as shown in Map 2. The soil analysis for $\mathrm{pH}, \mathrm{EC}, \mathrm{CaCO}_{3}$ $\%$, soluble cations, soluble anions and particle size distribution were carried out using the methods described by Page et al. (1982) as presented (Yehia et al, 2014). Also, the organic matter was determined using Walkley-Black wet combustion method (Tan, 1996). The statistical characterization of soil samples are presented in Table (1).

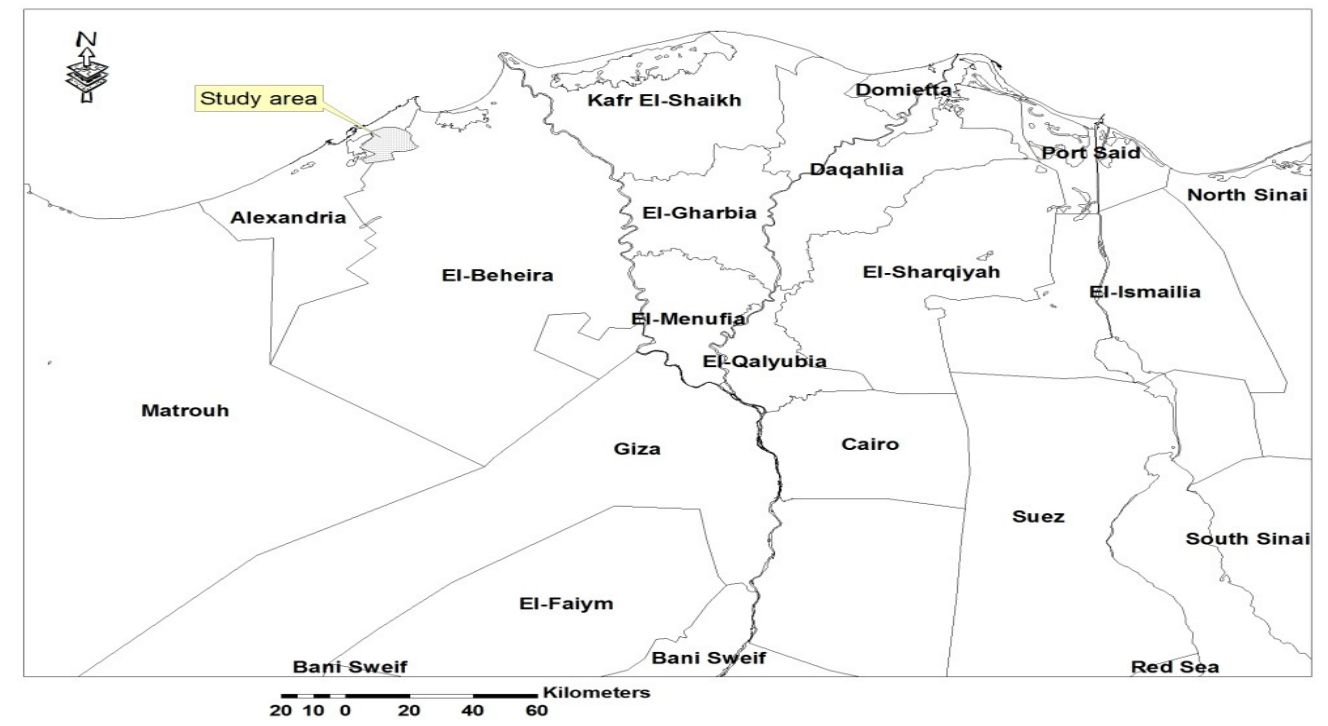

Map (1): The general location of the study area 


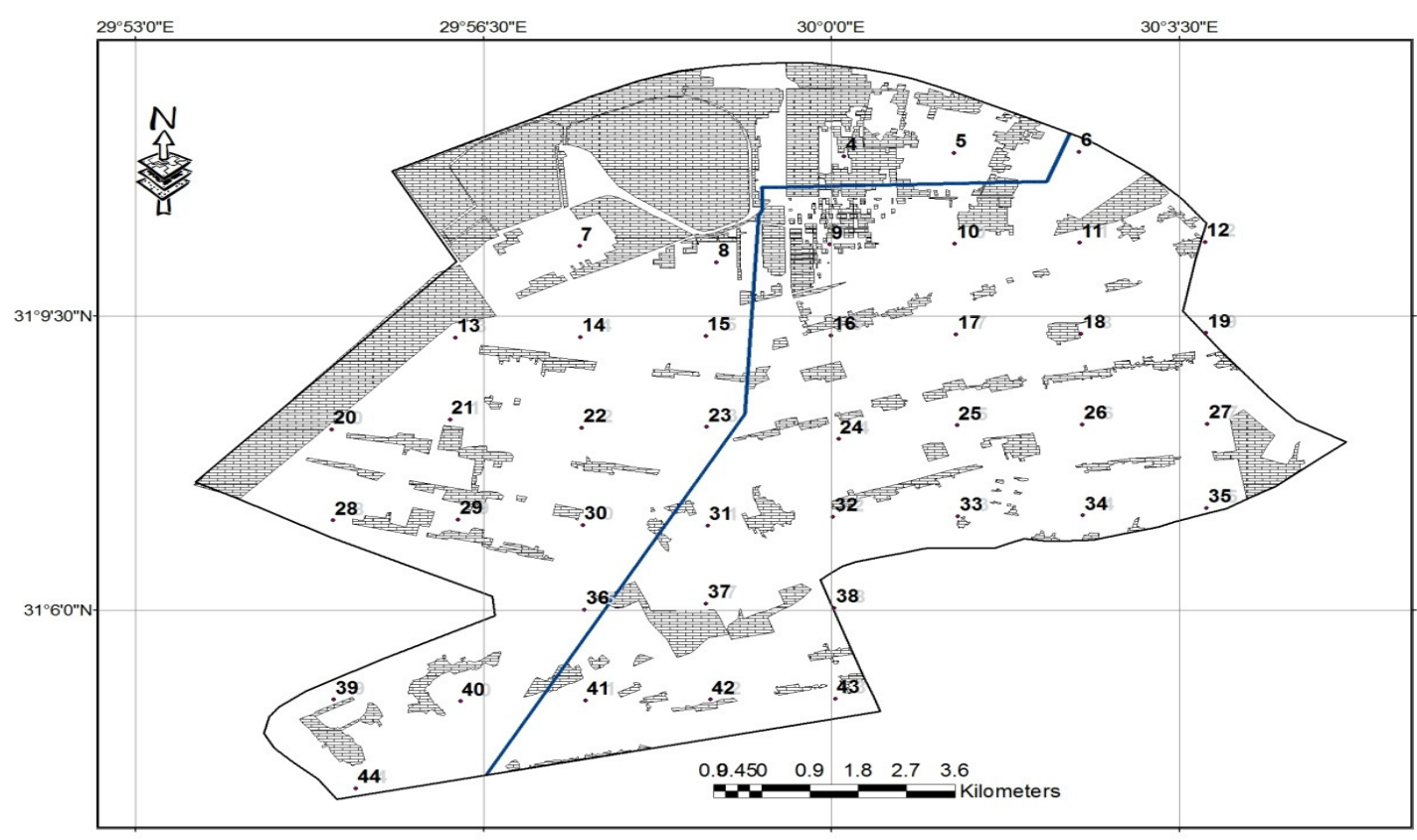

Map 2: The soil sample locations of the study area

\section{Total heavy metals measurement}

Total concentrations of heavy metals $(\mathrm{Pb}, \mathrm{Cr}$, and $\mathrm{Zn}$ ) were determined by wet digestion in soil according to (Page et al., 1982); $1 \mathrm{~g}$ of collected surface soil was placed in a Teflon crucible $5 \mathrm{~mL} \mathrm{HNO}_{3}, 10 \mathrm{~mL} \mathrm{HF}$ and $12 \mathrm{~mL} \mathrm{HClO}_{4}$ were added in to the soil and oscillated for $10 \mathrm{~h}$ then under constant temperature $\left(80^{\circ} \mathrm{C}\right)$. After the sample was almost dried, $10 \mathrm{~mL}$ nitric acid (1:1) was added to dissolve the solids continually. The dissolved soil sample was transferred constantly to 50 $\mathrm{mL}$ volumetric flask to determine the total contents of the tested metals in soils.

\section{Estimating forms of the tested heavy metals}

Sequential extraction procedure was carried out using $2.0 \mathrm{~g}$ soil was involved to the five following steps (Tessier et al., 1979; Tessier et al., 1980):

\section{Water soluble:}

Samples of finely grounded air-dried soil were transferred top shaking bottle followed by $16 \mathrm{ml}$ of deionized water and samples were shaken on a reciprocating shaker for $1 \mathrm{~h}$. The suspension was centrifuged for 30 minutes and then the supernatant was filtered through whatman 42 filter papers.

\section{Exchangeable fraction:}

The same soil sample was placed in contact with a high ionic strength solution, in order to release the so-called exchangeable fraction of metal by altering the sorption-desorption superficial processes. In this step $16 \mathrm{ml}$ of $1 \mathrm{M} \mathrm{NH}_{4} \mathrm{OAc}$ $(\mathrm{pH}=7)$ were added to the sample and the supernatant was shaken for $2 \mathrm{~h}$. 


\section{Fraction bound to carbonate:}

The fraction of metal bound to carbonates, present in the sample, may be selectively labialized by varying the $\mathrm{pH}$ of the sample itself with a slightly acidic extraction solution. $16 \mathrm{ml}$ of $1 \mathrm{M}$ of $\mathrm{CH}_{3} \mathrm{COONa}$, plus $\mathrm{CH}_{3} \mathrm{COOH}(\mathrm{pH}=5)$ were added to the residue obtained from the former extraction, and the suspension was shaken for $5 \mathrm{~h}$.

\section{Fraction bound to iron and manganese oxides:}

The residue from fraction 3 was extracted under mild reducing conditions of $13.9 \mathrm{~g}$ of hydroxylamine hydrochloride $\left(\mathrm{NH}_{2} \mathrm{OH} \cdot \mathrm{HCl}\right)$ was dissolved in $500 \mathrm{~mL}$ distilled water to prepare $0.4 \mathrm{M} \mathrm{NH} \mathrm{N}_{2} \mathrm{OH} \cdot \mathrm{HCl}$. The residue was extracted with $20 \mathrm{~mL}$ $0.4 \mathrm{M} \mathrm{NH} \mathrm{N}_{2} \mathrm{OH} \cdot \mathrm{HCl}$ in $25 \%(\mathrm{v} / \mathrm{v})$ acetic acid with agitation at $96^{\circ} \mathrm{C}$ in a water bath for 6 hours. The extracted metals solution was decanted from the residual soil which was used for the next extraction.

\section{Fraction bound to organic matter and to sulphides:}

The residue from fraction 4 was oxidized as follows: $6 \mathrm{~mL} 0.02 \mathrm{M} \mathrm{HNO}_{3}$ and $10 \mathrm{~mL} 30 \%(\mathrm{v} / \mathrm{v})$ hydrogen peroxide was added to the residue from fraction 4 . The mixture was heated to $85^{\circ} \mathrm{C}$ in a water bath for 2 hours with occasional agitation and allowed to cool down. Another $6 \mathrm{~mL}$ of $30 \%$ hydrogen peroxide, adjusted to $\mathrm{pH}$ 2 with $\mathrm{HNO}_{3}$, was then added. The mixture was heated again at $85^{\circ} \mathrm{C}$ for $3 \mathrm{~h}$ with occasional agitation and allowed to cool down. Then, $10 \mathrm{~mL}$ of $3.2 \mathrm{M}$ ammonium acetate in $20 \%(\mathrm{v} / \mathrm{v})$ nitric acid was added, followed by dilution to a final volume of $50 \mathrm{~mL}$ with de-ionized water.

\section{Residual fraction:}

It is the metal fraction present as scatter within the crystal lattice of the rocks and minerals that constitutes the soil. It was calculated from the difference between the concentration of total metal and the sum of the first four fractions.

After each extraction, the suspension was subjected to centrifugation for 20 min at $4000 \mathrm{rpm}$. The solution was separated, while the precipitate was washed with $10 \mathrm{ml}$ of high purity water and centrifuged again for $5 \mathrm{~min}$. The washing water then was added to the supernatant, while the precipitate was used for the subsequent extractions. The extracts were diluted to $50 \mathrm{ml}$ by distilled water and analyzed for the selected heavy metals by atomic absorption spectrometer (Analytike Jena,Germany)®.

\section{Classic statistical analysis and Kriging maps}

The important information about variables is provided by descriptive statistics using the Statistical Package for Social Science (SYSTAT) version 12.0. Measures of tendency of variables were determined by mean and median as well as computing the dispersion of a variable in variance, standard deviation, Coefficient of Variation (CV) and range (Cen et al., 2006). Geostatistical analyses of any parameter readings were calculated for their semivariogram. A semivariogram indicates autocorrelation as a function of distance (semivariance versus distance separation) to plot spatial variability (Shibusawa, 1998). It's components which include fitted model type, nugget variance $(\mathrm{CO})$, structural variance sill $(\mathrm{CO}+\mathrm{C})$, range (A), Residual Sum of Square (RSS), coefficient $\left(r^{2}\right)$ and proportion 
J. Adv. Agric. Res. (Fac. Agric. Saba Basha)

$(\mathrm{C} 0 /[\mathrm{C}+\mathrm{C}])$ were calculated by Geostatistical analysis software through $\mathrm{GS}^{+}$ Geostatistics for the Environmental Science (Gamma Design Software, Version 9, LLC Plainwell, Michigan). Variability has been identified as spatial, temporal and predictive. Spatial variability of total heavy metal contents was obtained in this study to monitor difference in maps of this measured parameter. These data were interpolated using ArcGIS 10.1 through spatial analysis extension on semivariogram results for Geostatistical Software $\left(\mathrm{GS}^{+}\right)$.

\section{RESULTS AND DISCUSSION}

\section{Characterization of the studied soils}

The minimum, maximum and average values of main physical and chemical properties of soil are shown in Table 1. The data show that the studied soils are characterized by sandy loam to sandy clay loam texture in most samples. Data of total soluble salts, as expressed by the electrical conductivity and sodium adsorption ratio indicate that most of the studied soils are characterized by their moderate to high EC and SAR values. The EC values ranged between 0.77 and $10.91 \mathrm{dS} / \mathrm{m}$, SAR values being in the range from 2.05 to $16.00 \mathrm{dSm}^{-1}$, total carbonate content ranged between 2 and 34\%. pH values ranged between7.92 and 8.83. The amounts of sand, silt and clay varied from 47.70 to $83.04,2.00$ to 17.74 and 8.96 to $44.00 \%$, respectively.

Table (1). Statistical parameters of the estimated properties and total heavy metals of the soil samples

\begin{tabular}{|c|c|c|c|c|c|c|c|}
\hline \multirow{2}{*}{$\begin{array}{c}\text { Soil } \\
\text { Properties }\end{array}$} & \multirow{2}{*}{ Average } & \multicolumn{2}{|c|}{ Range } & \multirow{2}{*}{ SD } & \multirow{2}{*}{ Median } & \multirow{2}{*}{ CV \% } & \multirow{2}{*}{ Var. } \\
\hline & & Min. & Max. & & & & \\
\hline $\mathrm{pH}$ & 8.17 & 7.92 & 8.83 & 0.19 & 8.18 & 2.31 & 0.04 \\
\hline $\mathrm{EC}, \mathrm{dSm}^{-1}$ & 3.32 & 0.77 & 10.91 & 2.28 & 2.81 & 69.00 & 5.19 \\
\hline $\mathrm{CaCO}, \%$ & 15.60 & 2.00 & 34.00 & 9.90 & 18.50 & 64.00 & 98.00 \\
\hline O.M,\% & 1.80 & 0.28 & 3.76 & 0.79 & 1.88 & 43.89 & 0.62 \\
\hline SAR & 7.59 & 2.05 & 16.00 & 4.54 & 7.39 & 1.46 & 20.64 \\
\hline \multicolumn{8}{|c|}{ Soluble Cations $\left(\mathrm{meqL}^{-1}\right)$} \\
\hline $\mathrm{Ca}^{+2}$ & 7.44 & 1.00 & 34.00 & 6.83 & 5.00 & 92.00 & 46.64 \\
\hline $\mathrm{Mg}^{+2}$ & 9.43 & 1.00 & 31.00 & 7.70 & 6.00 & 82.00 & 59.23 \\
\hline $\mathrm{Na}^{+}$ & 23.18 & 4.00 & 80.00 & 18.85 & 19.00 & 81.00 & 355.40 \\
\hline $\mathrm{K}^{+}$ & 0.46 & 0.12 & 1.20 & 0.28 & 0.40 & 61.00 & 0.08 \\
\hline \multicolumn{8}{|c|}{ Soluble Anions( meqL $\left.^{-1}\right)$} \\
\hline $\mathrm{HCO}^{-}$ & 3.66 & 1.00 & 10.00 & 2.80 & 2.50 & 77.00 & 7.84 \\
\hline $\mathrm{Cl}^{-}$ & 21.07 & 3.00 & 101.50 & 19.80 & 17.50 & 94.00 & 391.95 \\
\hline $\mathrm{SO} 4=$ & 15.57 & 0.30 & 56.66 & 13.62 & 13.66 & 87.00 & 185.46 \\
\hline \multicolumn{8}{|c|}{ Particle size distribution (\%) } \\
\hline Sand & 69.02 & 47.70 & 83.04 & 8.98 & 69.70 & 13.01 & 0.64 \\
\hline Silt & 10.34 & 2.00 & 17.74 & 3.93 & 11.00 & 38.01 & 15.44 \\
\hline Clay & 20.70 & 8.96 & 44.00 & 8.29 & 12.20 & 40.05 & 68.72 \\
\hline \multicolumn{8}{|c|}{ Total Heavy Metals $\left(\mathrm{mgkg}^{-1}\right)$} \\
\hline $\mathrm{Pb}$ & 25.64 & 14.73 & 65.05 & 11.20 & 22.20 & 43.68 & 125.48 \\
\hline $\mathrm{Cr}$ & 21.20 & 2.72 & 47.83 & 10.04 & 20.04 & 47.36 & 100.86 \\
\hline $\mathrm{Zn}$ & 85.45 & 45.18 & 142.20 & 24.81 & 84,85 & 29.03 & 615.56 \\
\hline
\end{tabular}

SD: standard deviation; CV: Variation coefficient; Var: Variance 


\section{Total concentrations of $\mathrm{Pb}, \mathrm{Cr}$ and $\mathrm{Zn}$ in soil}

The concentration of heavy metals in the soils of Abis area was determined and the statistical parameters of the estimated total heavy metals in the soil samples are presented in Table 1. The mean concentrations of $\mathrm{Pb}, \mathrm{Cr}$ and $\mathrm{Zn}$ were $25.64,21.20,85.18 \mathrm{mgkg}^{-1}$, respectively. High metal concentrations in the soils were found for $\mathrm{Zn}$, while $\mathrm{Cr}$ had the least concentrations. The mean values of the heavy metal contents can be ranked in the order of $\mathrm{Zn}>\mathrm{Pb}>\mathrm{Cr}$ (Table 1). According to Jones and Jarvis (1981), processes of metal mobilizationimmobilization are affected by a variety of soil properties. To examine this influence, data from this study were statistically analyzed to illustrate the relationship among total content of heavy metals, $\mathrm{EC}, \mathrm{pH}$, organic matter, clay, sand and silt are listed in Table 2. A positive correlation was recorded between $\mathrm{Zn}$ and clay $\left(r=0.358^{*}\right)$. Also, a negative correlation between total $\mathrm{Zn}$ and sand $(r=-$ $0.404^{* *}$ ) was observed. Geostatistical analyses of total heavy metals were presented according to its semivariogram. As mentioned in material and method, semivariogram has different components and the variograms of total $\mathrm{Cr}, \mathrm{Pb}$ and $\mathrm{Zn}$ were prepared as shown in Fig. 1., Fig.2 and Fig.3. The classification approach using raster calculator, which was available in the spatial analyst for calculating the total $\mathrm{Pb}, \mathrm{Cr}$ and $\mathrm{Zn}$ and calculated maps were produced. The classification technique of manual, which was introduced by ArcGIS software, was selected to visual variability as groups. This study decided to zone the area into 5 zones which could be manageable and also easy to compare.

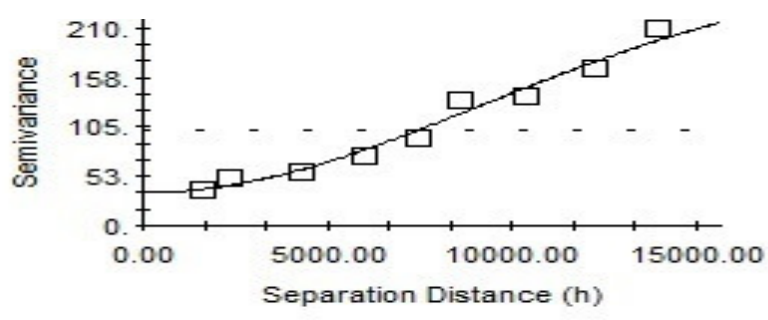

Fig (1) : Isotropic semivariogram of total $\mathrm{Cr}$, Exponential model $(\mathrm{C} 0=35.3$; $C 0+C=271.5 ; A O=12970 ; R^{2}=0.976 ; R S S=665$ )

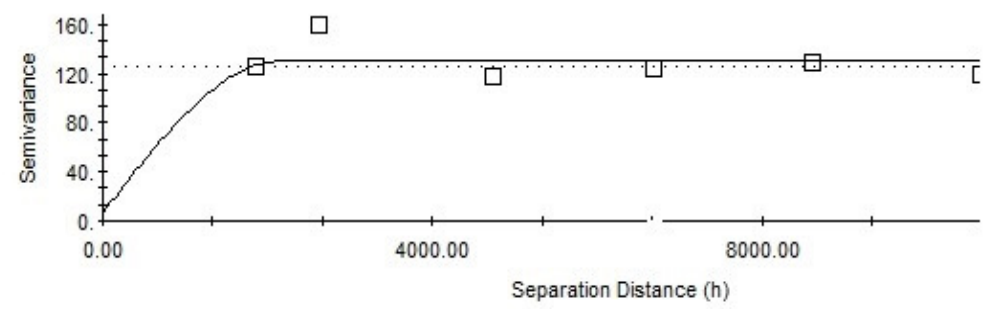

Fig(2): Isotropic semivariogram of total $\mathrm{Pb}$, Spherical model, $(\mathrm{C} 0=7.10 ; \mathrm{C} 0+\mathrm{C}$ $=130.4 ; A o=2150 ; R^{2}=0.008 ; R S S=1190$ ) 


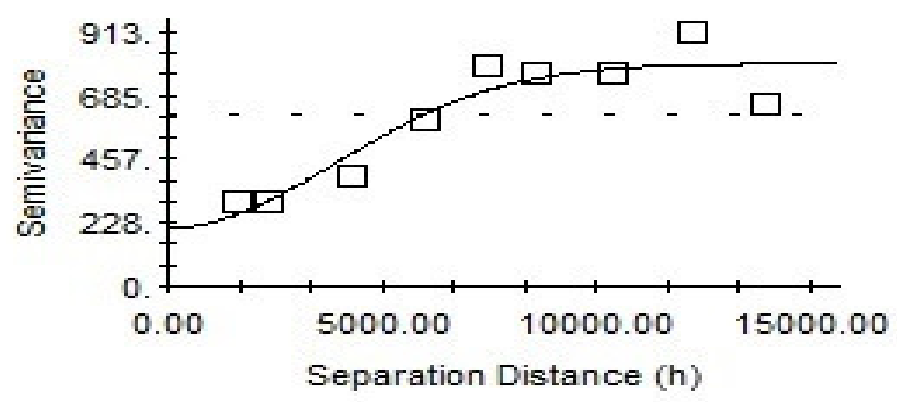

Fig(3): Isotropic semivariogram of total $\mathrm{Zn}$, Gaussian model $(\mathrm{C} 0=210 ; \mathrm{C} 0+\mathrm{C}=$ 799.5; $\mathrm{Ao}=5530 ; \mathrm{R}^{2}=0.87 ; \mathrm{RSS}=52595$ )

Map 3 shows the distribution of total $\mathrm{Pb}$ in the soil representing the study area using weighted average. It is clear that, total $\mathrm{Pb}$ is variable and ranged from 23 to $32 \mathrm{mg} \mathrm{kg}^{-1}$ soil. The dominant total $\mathrm{Pb}$ class was 23 to $25 \mathrm{mg} \mathrm{kg}^{-1}$ soil covered about $29.17 \%$ of the area and mostly found in the northern part of the study area and is found in Alexandria Governorate. Also another dominant class had 26-27 $\mathrm{mg} \mathrm{kg}^{-1}$ covered about $38.16 \%$ and mostly found in Behira Governorate.

Total $\mathrm{Cr}$ ranged from 0.2 to 43 and classified into five classes as shown in Map 4. The dominant classes had 25 to $31 \mathrm{mg} / \mathrm{kg}$ soil and covered about $27.06 \%$ of the area and mostly found in El Behira Governorate. Also, another dominant class had 20 to $24 \mathrm{mg} \mathrm{kg}^{-1}$ soil covered about $30.63 \%$ of the area and found in Alexandria Governorate.

Total $\mathrm{Zn}$ contents ranged from 48 to $130 \mathrm{mg} \mathrm{kg}^{-1}$ soil and classified into five classes as shown in Map 5. The dominant classes had 48 to $68 \mathrm{mg} \mathrm{kg}^{-1}$ soil and covered about $32.07 \%$ of the area and mostly found in Alexandria governorate. The class which had the higher content of $\mathrm{Zn}\left(120\right.$ to $\left.130 \mathrm{mg} \mathrm{kg}^{-1}\right)$ was found in Behira governorate and covered about $9.65 \%$ of the area.

Table (2): The correlation coefficients between total heavy metals and some properties of the soil samples

\begin{tabular}{cccccccc}
\hline $\begin{array}{c}\text { Heavy } \\
\text { metals }\end{array}$ & $\begin{array}{c}\mathbf{E C} \\
\mathbf{d S} / \mathbf{m}\end{array}$ & $\mathbf{p H}$ & $\mathbf{C a C O}_{3} \%$ & $\mathbf{O . M .} \%$ & Clay \% & Silt \% & Sand \% \\
\hline $\mathbf{P b}$ & 0.002 & -0.251 & -0.007 & 0.074 & 0.120 & -0.271 & -0.014 \\
$\mathbf{C r}$ & -0.118 & -0.100 & -0512 & -0.157 & 0.281 & -0.176 & -0.155 \\
$\mathbf{Z n}$ & -0.088 & 0.069 & 0.144 & -0.117 & $0.358^{*}$ & 0.129 & $-0.404^{* *}$ \\
\hline
\end{tabular}

${ }^{*}$ Significant at $5 \%$ level,

${ }^{* *}$ Significant at $1 \%$ level 


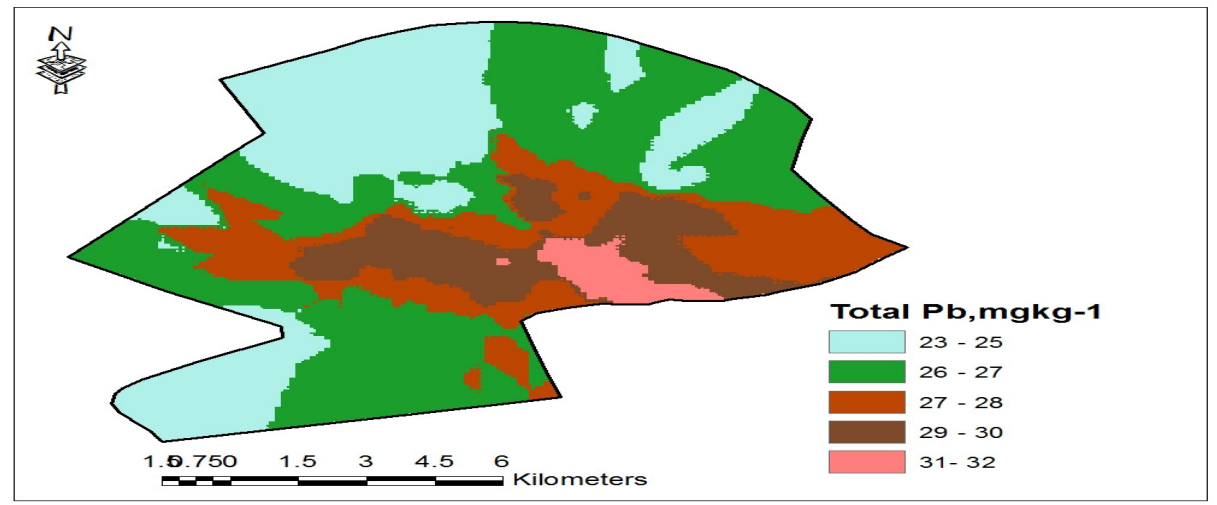

Map (3): Distribution of total $\mathrm{Pb}$ in the top soil of Abis area

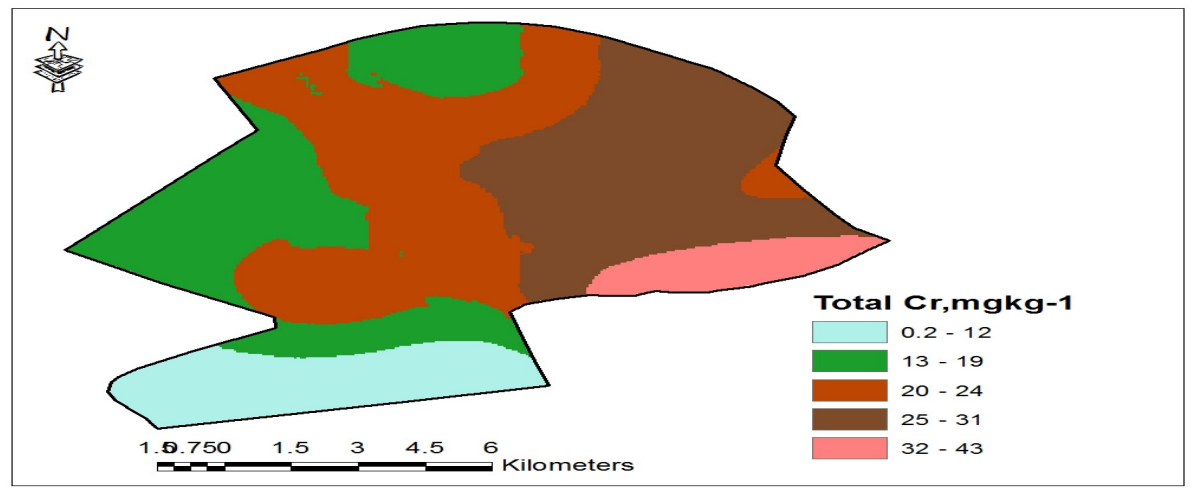

Map (4): Distribution of total $\mathrm{Cr}$ in the top soil of Abis area

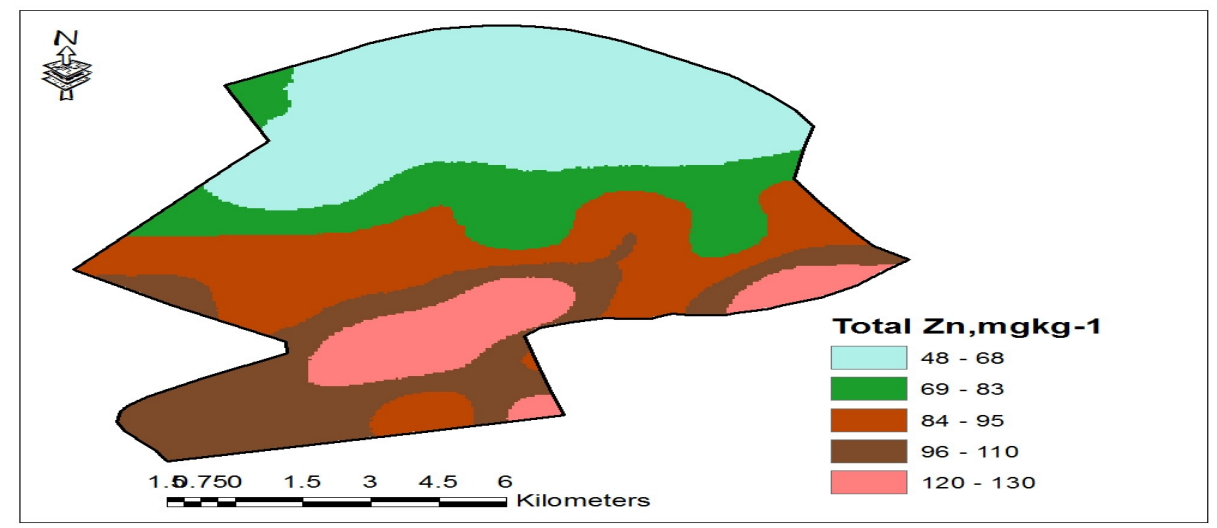

Map (5): Distribution of total $\mathrm{Zn}$ in the top soil of Abis area

However, total heavy metals contents were found to be in the permissible limits reference values of heavy metals for agricultural soils according to the FAO (2001). The values of the limits reference of $\mathrm{Zn}, \mathrm{Pb}$ and $\mathrm{Cr}$ were $300,100,100 \mathrm{mgkg}^{-1}$ soil, respectively. 


\section{Geochemical fractions of $\mathrm{Pb}, \mathrm{Cr}$, and $\mathrm{Zn}$ in soil}

Metal chemical speciation carried out by sequential extraction is essential to the metal mobility (Tessier et al, 1979). The obtained results (Tables 3 and 4) showed that the amounts of heavy metals extracted from each fraction vary widely. The order of mobility of the metals considering their abundance in the fractions is: soluble+ exchangeable $>$ bound to carbonate $>$ bound to oxides $>$ bound to organics > residuals (Tessier et al, 1979). Oxides exist as nodules and cement between particles. These oxides hold trace metals and can be mobilized under reducing and acidic conditions. The organic phase is relatively stable in nature but can be mobilized under strong oxidizing conditions due to degradation of organic matter (Haung et al., 2007).

\subsection{Fractionation of $\mathrm{Pb}$}

The statistical parameters of $\mathrm{Pb}$ fractions and their percentages of the total extracted are presented in Tables 3 and 4, respectively. The dominant fraction for lead in soils of Abis area was the residual fraction. This chemical form was closely followed by the exchangeable fraction. The partitioning of $\mathrm{Pb}$ varied among all the fractions. More than $80 \%$ of $\mathrm{Pb}$ (Table 4) was held in the residual form, which indicates the bioavailability potential of $\mathrm{Pb}$. The stability of metals bound to sediments as inorganic compounds (metal oxides, hydroxides, carbonate and sulphides) is controlled primarily by the $\mathrm{pH}$ system (Poulton et al., 1988). The order of the partitioning of $\mathrm{Pb}$ in the soils of Abis area is $\mathrm{F} 6>\mathrm{F} 2>\mathrm{F} 3>\mathrm{F} 4>\mathrm{F} 5>\mathrm{F} 1$. This agrees with those found by Ramirez et al., (2005), who reported that $\mathrm{Pb}$ was mostly associated with the residual fraction.

\subsection{Fractionation of $\mathrm{Cr}$}

Chromium is mostly abundant in residual fraction (Tables 3 and 4). The abundance of $\mathrm{Cr}$ in residual phase ranged between 0.06 to $43.88 \mathrm{mg} \mathrm{kg}^{-1}$ soil with a mean of $15.58 \mathrm{mg} \mathrm{kg}^{-1}$ soil (Table 3) and $65.63 \%$ of total (Table 4). The calcium carbonate fraction is the second in abundance after the residual fraction, the range was from 0.22 to $7.41 \mathrm{mg} \mathrm{kg}^{-1}$ with a mean value of $2.70 \mathrm{mg} \mathrm{kg}^{-1}$ soil and the abundance was $18.04 \%$ of total. Abundance of $\mathrm{Cr}$ in other geochemical phases was very low. This means that $\mathrm{Cr}$ was less mobile in this environment.

\subsection{Fractionation of $\mathrm{Zn}$}

Zinc is mostly abundant in residual fraction in the range from 37.68 to $135.24 \mathrm{mg} \mathrm{kg}^{-1}$ with a mean value of $79.13 \mathrm{mg} \mathrm{kg}^{-1}$ soil (Table 3 ) and $91.33 \%$ of total (Table 4) while in the oxide fraction, the range of $\mathrm{Zn}$ was from 1.06 to $9.13 \mathrm{mg}$ $\mathrm{kg}^{-1}$ with a mean value of $2.69 \mathrm{mg} \mathrm{kg}^{-1}$ soil (Table 3 ) and the abundance was $3.66 \%$ of total. Abundance of $\mathrm{Zn}$ in other fractions was low. Also, $\mathrm{Zn}$ in this environment was less mobile since the metals which were mostly abundant occurred in the Residual fraction. This is in agreement with the data repected by Zerbe et al., (1999). 
Table (3): Range, mean, standard deviation (SD) of heavy metals in different geochemical fractions of soil samples

\begin{tabular}{|c|c|c|c|c|c|c|c|c|c|c|c|c|}
\hline \multirow{4}{*}{$\begin{array}{l}\text { Geochemical } \\
\text { Fractions }\end{array}$} & \multicolumn{12}{|c|}{ Heavy metals(mgkg ${ }^{-1}$ Soil) } \\
\hline & \multicolumn{4}{|c|}{$\mathbf{P b}$} & \multicolumn{4}{|c|}{$\mathrm{Cr}$} & \multicolumn{4}{|c|}{ Zn } \\
\hline & \multicolumn{2}{|c|}{ Range } & \multirow{2}{*}{ Mean } & \multirow[b]{2}{*}{ SD } & \multicolumn{2}{|c|}{ Range } & \multirow{2}{*}{ Mean } & \multirow{2}{*}{ SD } & \multicolumn{2}{|c|}{ Range } & \multirow{2}{*}{ Mean } & \multirow{2}{*}{ SD } \\
\hline & Min & Max & & & Min & Max & & & Min & Max & & \\
\hline F1 & 0.00 & 1.38 & 0.46 & 0.41 & 0.00 & 1.32 & 0.03 & 0.21 & 0.0 & 0.53 & 0.01 & 0.08 \\
\hline F2 & 0.19 & 2.81 & 1.08 & 0.57 & 0.00 & 3.98 & 1.26 & 0.83 & 0.0 & 1.33 & 0.40 & 0.22 \\
\hline $\mathrm{F} 1+\mathrm{F} 2$ & 0.19 & 3.66 & 1.62 & 0.76 & 0.00 & 3.98 & 1.29 & 0.89 & 0.0 & 1.33 & 0.41 & 0.22 \\
\hline F3 & 0.11 & 3.28 & 0.76 & 0.83 & 0.22 & 7.41 & 2.70 & 1.46 & 0.70 & 3.29 & 1.65 & 1.03 \\
\hline F4 & 0.00 & 6.22 & 0.60 & 1.26 & 0.14 & 0.93 & 0.35 & 0.16 & 1.06 & 9.13 & 2.69 & 1.69 \\
\hline F5 & 0.11 & 0.99 & 0.57 & 0.27 & 0.26 & 3.0 & 1.29 & 0.65 & 0.11 & 5.69 & 1.57 & 1.46 \\
\hline F6 & 10.22 & 57.41 & 22.50 & 11.02 & 0.06 & 43.88 & 15.58 & 9.72 & 37.68 & 135.24 & 79.13 & 25.24 \\
\hline
\end{tabular}

F1: Soluble- fraction; F2: Exchangeable fraction; F3: Carbonate fraction F4: Fe+Mn-oxide fraction; F5: Organic matter fraction;

F6: Residual fraction

Table (4): Range, mean, standard deviation (SD) of heavy metals (\% of total) in different geochemical fractions of soil samples

\begin{tabular}{|c|c|c|c|c|c|c|c|c|c|c|c|c|}
\hline \multirow{4}{*}{$\begin{array}{c}\text { Geochemical } \\
\text { Fractions }\end{array}$} & \multicolumn{12}{|c|}{ Heavy metals(mgkg ${ }^{-1}$ Soil) } \\
\hline & \multicolumn{4}{|c|}{$\mathrm{Pb}$} & \multicolumn{4}{|c|}{$\mathrm{Cr}$} & \multicolumn{4}{|c|}{$\mathrm{Zn}$} \\
\hline & \multicolumn{2}{|c|}{ Range } & \multirow{2}{*}{ Mean } & \multirow{2}{*}{ SD } & \multicolumn{2}{|c|}{ Range } & \multirow{2}{*}{ Mean } & \multirow[b]{2}{*}{ SD } & \multicolumn{2}{|c|}{ Range } & \multirow[b]{2}{*}{ Mean } & \multirow{2}{*}{ SD } \\
\hline & Min & Max & & & Min & Max & & & Min & Max & & \\
\hline F1 & 0.00 & 7.43 & 2.19 & 2.15 & 0.00 & 6.62 & 0.16 & 1.03 & 0.00 & 0.86 & 0.02 & 0.13 \\
\hline F2 & 0.87 & 15.39 & 5.09 & 3.33 & 0.00 & 49.87 & 6.57 & 7.80 & 0.00 & 4.17 & 0.58 & 0.63 \\
\hline $\mathrm{F} 1+\mathrm{F} 2$ & 0.87 & 18.73 & 7.26 & 4.19 & 0.00 & 49.87 & 6.73 & 7.96 & 0.00 & 4.17 & 0.60 & 0.63 \\
\hline F3 & 0.18 & 4.76 & 1.43 & 1.20 & 0.97 & 68.03 & 18.04 & 15.77 & 0.93 & 4.03 & 1.94 & 0.90 \\
\hline F4 & 0.00 & 18.89 & 2.58 & 4.85 & 0.49 & 16.05 & 2.92 & 3.56 & 0.98 & 11.64 & 3.66 & 2.81 \\
\hline F5 & 0.31 & 6.32 & 2.67 & 1.62 & 1.94 & 33.09 & 7.56 & 5.35 & 0.13 & 8.76 & 2.14 & 2.29 \\
\hline F6 & 66.45 & 96.19 & 85.95 & 6.96 & 1.88 & 91.74 & 65.63 & 23.46 & 77.53 & 96.86 & 91.33 & 5.10 \\
\hline
\end{tabular}

F1: Soluble- fraction; F2: Exchangeable fraction; F3: Carbonate fraction F4: Fe+Mn-oxide fraction; F5: Organic matter

fraction; F6: Residual fraction 
J. Adv. Agric. Res. (Fac. Agric. Saba Basha)

Table(5): Correlation between some soil properties and the fractions of the tested heavy metals

\begin{tabular}{|c|c|c|c|c|c|c|c|c|}
\hline & $\begin{array}{c}\text { Metals } \\
\text { Fractions }\end{array}$ & $\mathrm{pH}$ & $\begin{array}{c}\mathrm{EC} \\
\mathrm{dS} / \mathrm{m}\end{array}$ & $\begin{array}{c}\mathrm{CaCO}_{3} \\
\%\end{array}$ & $\begin{array}{c}\text { O.M } \\
\%\end{array}$ & $\begin{array}{c}\text { Clay } \\
\%\end{array}$ & $\begin{array}{c}\text { Silt } \\
\%\end{array}$ & $\begin{array}{c}\text { Sand } \\
\%\end{array}$ \\
\hline \multirow{5}{*}{$\mathbf{P b}$} & Exchangeable & -0.017 & 0.186 & 0.091 & -0.106 & 0.059 & 0.262 & -0.166 \\
\hline & Carbonates & -0.175 & 0.271 & 0.242 & -0.065 & 0.255 & 0.099 & -0.272 \\
\hline & Oxides & 0.167 & -0.116 & $-0.310^{*}$ & 0.203 & -0.045 & -0.078 & 0.075 \\
\hline & Organic & 0.267 & -0.087 & $0.361^{*}$ & 0.213 & -0.132 & 0.137 & 0.053 \\
\hline & Residuals & 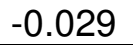 & -0. & 8 & -0. & 0. & -0.290 & 03 \\
\hline \multirow{5}{*}{$\mathrm{Cr}$} & Exchangeable & 0 & 0.021 & -0.099 & 0.055 & -0.3 & -0.109 & $0.368^{*}$ \\
\hline & Carbonates & 0 & -0.0 & 0 . & 0.102 & & $-0.338^{*}$ & $11^{*}$ \\
\hline & Oxides & -0.300 & 0.186 & $0.332^{*}$ & -0.20 & -0.174 & 0.246 & 0.051 \\
\hline & Organic & -0.055 & -0.065 & $-0.571^{*}$ & -0.247 & -0.099 & -0.215 & 0.184 \\
\hline & Residuals & -0.158 & 0.152 & $-0.510^{\star *}$ & -0.168 & 0.359 & -0.105 & -0.257 \\
\hline \multirow{5}{*}{ Zn } & Exchangeable & -0.141 & -0.198 & -0.062 & 0.031 & 0.268 & 0.001 & -0.266 \\
\hline & Carbonates & -0.072 & -0.083 & 0.265 & -0.059 & 0.262 & 0.071 & -0.263 \\
\hline & Oxides & -0.056 & -0.044 & $-0.511^{* *}$ & -0.210 & 0.026 & -0.170 & 0.055 \\
\hline & Organic & -0.065 & -0.065 & $-0.505^{\star \star}$ & -0.174 & -0.104 & -0.289 & 0.215 \\
\hline & $\mathrm{Re}$ & -0.077 & -0.032 & 0.194 & -0.090 & $0.343^{*}$ & 0.153 & $-0.400^{*}$ \\
\hline
\end{tabular}

${ }^{*}$ Significant at $5 \%$ Level, ** Significant at $1 \%$ Level

The results of the sequential extraction show that most of $\mathrm{Pb}, \mathrm{Cr}$ and $\mathrm{Zn}$ are strongly retained in the residual fraction in all soils. These heavy metals are contained in the crystal lattices of minerals with strong bindings and consequently they will not be released into the environment. Metals present in the residual fraction are a measure of the extent of environmental pollution. The higher the metals present in this fraction, the lower the degree of pollution (Howari and Banat, 2001). Sum of concentrations of metals in different geochemical fraction can be used to express the potential mobility of metals. The exchangeable fraction represents the mobility and bioavailability heavy metal fraction. In this phase, the heavy metals have the more labile bounds and can be easily released into the environment. The presence of heavy metals in this fraction where they can be taken up by plants from the soils is the most hazardous to the ecosystem.

According to Jones and Jarvis (1981), processes of metal mobilizationimmobilization are affected by a variety of soil properties. To examine this influence, correlations between $\mathrm{pH}$, carbonate, organic matter and clay percentages and contents of $\mathrm{Pb}, \mathrm{Cr}$ and $\mathrm{Zn}$ in five chemical fractions' of the sequential extraction have been calculated for all soil samples. As can be seen in (Table 5), a significant negative correlation between the carbonate contents and organic and residual fractions of $\mathrm{Cr}$ was observed. On the other hand, a positive correlation was found with oxide fraction. Also, a negative correlation and positive correlation were observed for oxides and organic fractions respectively. $\mathrm{Cr}$ from the exchangeable and carbonates phases is also positively related to sand contents. Zinc from the oxide and organic fractions are negatively related to $\mathrm{CaCO}_{3}$ content. 
Also, zinc in residual fraction is positively related to clay contents and negatively related to sand contents.

\section{Mobility and potential mobility of $\mathrm{Pb}, \mathrm{Cr}$, and $\mathrm{Zn}$ in soil}

The used sequential extraction enables to assess the bioavailability and potential mobility of metals in soils. Assuming that bioavailability is related to solubility, then metal mobilization decreases in the order: soluble $>$ exchangeable $>$ carbonate $>\mathrm{Fe}-\mathrm{Mn}$ oxide $>$ organic $>$ residual ( $\mathrm{Ma}$ and Rao, 1997). Results gained by sequential extraction procedures can be summarized using the concepts of mobility factor (MF) and potential mobility (PM). Elements mobility in a soil is determined from mobility factor which is calculated from the following equation as described by (Kabala and Singh 2001) and (Oluwatson, 2008).

$$
\text { Mobility Factor }(\mathrm{MF})=
$$

$$
[(\mathrm{F} 1+\mathrm{F} 2 / \text { Total }) \times 100]
$$

Also, the potential mobility (PM) can be calculated according to Ashraf et al. (2012) as follows:

$$
\begin{aligned}
& \text { Potential Mobility }(\mathrm{PM})= \\
& \qquad \mathrm{F} 1+\mathrm{F} 2+\mathrm{F} 3+\mathrm{F} 4+\mathrm{F} 5 / \text { Total } \times 100
\end{aligned}
$$

The mobility and potential mobility of heavy metals in soils are summarized in Table (6). The value of MF for elements provide information about their potential mobility in soils and availability to plants (Yusuf, 2007). The value of MF up to 10\% for any element indicates that this element is highly immobile and unavailable for plants (Torri and Lavado, 2008). In addition to that, the value of MF up to $50 \%$ or greater than $50 \%$ for a particular element suggests that this element is highly mobile and available for plants (Ahumada et al., 1999). Oluwatson et al. (2008) reported, while studying the availability and mobility of $\mathrm{Pb}$ and $\mathrm{Zn}$ in the urban soils of North-West Nigeria that the percentage of mobility factor (MF) for $\mathrm{Pb}$ and $\mathrm{Zn}$ varied from 5 to 6 , and 15 to $25 \%$, respectively in all soils. They concluded that $\mathrm{Pb}$ was highly stable in soils hence unavailable to plants. The average mobility factor for $\mathrm{Pb}, \mathrm{Cr}$ and $\mathrm{Zn}$ in the soils of Abis area is $7.31,6.74$ and $0.51 \%$, respectively. Therefore, these elements are highly stable in soil and unavailable to plants.

The average potential mobility of $\mathrm{Cr}$ was $34.79 \%$ (Table 6). From the result of the sequential extraction in all the studied soil samples, $\mathrm{Cr}$ was mostly abundant in the residual fraction and the abundance was lower in the soluble and exchangeable fractions. High abundance of a metal in the residual phase compared with its abundance in other geochemical phases indicates lower mobility of the metal in the environment. This showed that $\mathrm{Cr}$ would not easily be released to the environment and not toxic. Zinc is mostly abundant bound to residual and the average potential mobility of $\mathrm{Zn}$ was $8.25 \%$. Therefore, compared with other metals that were mostly abundant in the residue fraction, $\mathrm{Zn}$ was less available in the study soils. The average potential mobility of $\mathrm{Pb}$ is $15.05 \%$, which is lower than the potential mobility of $\mathrm{Cr}$ and $\mathrm{Zn}$ which had the least average potential mobility 
(8.25\%). From Table 6 , the order of average potential mobility of $\mathrm{Pb}, \mathrm{Cr}$ and $\mathrm{Zn}$ in the studied soils agrees with the percentage reduction in residual concentrations (Table 3).

Table (6) : Range, mean, standard deviation (S.D.) of mobility factor (\%) and potential mobility(\%)for the heavy metals in the studied soil samples

\begin{tabular}{cccccc}
\hline \multirow{2}{*}{$\begin{array}{c}\text { Heavy } \\
\text { metals }\end{array}$} & Mobility & \multicolumn{2}{c}{ Range } & \multirow{2}{*}{ Mean } & \multirow{2}{*}{ SD } \\
\cline { 3 - 4 } properties & Min & Max & & \\
\hline \multirow{2}{*}{$\mathbf{P b}$} & MF & 0.87 & 18.73 & 7.31 & 4.24 \\
& $\mathbf{P M}$ & 3.81 & 48.00 & 15.05 & 8.63 \\
\hline \multirow{2}{*}{$\mathbf{C r}$} & MF & 0.00 & 49.87 & 6.74 & 7.95 \\
& $\mathbf{P M}$ & 8.26 & 98.12 & 34.80 & 23.25 \\
\hline \multirow{2}{*}{$\mathbf{Z n}$} & $\mathbf{M F}$ & 0.00 & 1.67 & 0.51 & 0.27 \\
\hline
\end{tabular}

MF=Mobility factor, $\mathrm{PM}=$ Potential mobility

The potential mobility of the tested heavy metals were in the following order: $\mathrm{Cr}(34.80 \%)>\mathrm{Pb}(15.05 \%)>\mathrm{Zn}(8.25 \%)$. However, values of the percentage reduction in concentration for metals sometimes might be controlled not only by its speciation, changes in $\mathrm{pH}$ and salinity, but also by unknown factors (Haung et al., 2007). Metals with anthropogenic origin are mainly extracted in the first step of sequential extraction procedures while lithogenic metals are found in the last step of the process corresponding to the residual fraction (Ramirez et al., 2005). The $\mathrm{Cr}$ and $\mathrm{Pb}$ and $\mathrm{Zn}$ metals at Abis area, from the results of sequential extraction, were mostly lithogenic origin.

\section{CONCLUSION}

The results obtained from sequential extraction procedure showed that most of $\mathrm{Pb}, \mathrm{Cr}$ and $\mathrm{Zn}$ considered had the highest abundance in the residual fraction. This indicates that these metals were immobile. The largest proportions for $\mathrm{Pb}, \mathrm{Cr}$, and $\mathrm{Zn}$ were extracted in the residual fraction, in which metals are strongly retained in the soil minerals. This showed that soil in the environment was not likely to be polluted by these metals. The average potential mobility of $\mathrm{Pb}, \mathrm{Cr}$ and $\mathrm{Zn}$ in the soil was quite low especially for $\mathrm{Zn}$. The average potential mobility of the metals, arranged in decreasing order, was as follows: $\mathrm{Cr}>\mathrm{Pb}>\mathrm{Zn}$. The obtained results have given the present status of metal pollution in the studied area. Further research can be carried out on the speciation of other heavy metals in Abis area. 


\section{REFERENCES}

Ahumada, I., J. Mendoza and L. Ascar (1999). Sequential extraction of heavy metals in soils irrigated with wastewater. Communication Soil Sci Plant Analysis, 30: 1507-1519.

Ashraf, M.A., M.J. Maah and I. Yousoff (2012). Chemical speciation and potential mobility of Heavy metals in the soil of former Tin Mining catchments: The Scientific World Vol.2012, Article ID125608, Pages: 11, doi:10.1100/2012/125608 (ISI/SCOPUS Cited Publication).

Cen, H.,Y. Shao, H.Song and Y.He (2006). Non destructive estimation of rape nitrogen status using SPAD chlorophyll Meter. Proceeding of the 8th International conference on singal processing, (sp'06), IEEE Xplore press, Beijing, PP: 16 -20. Communication in Soil Science and Plant Analysis, 30: 1507 - 1519.

Cottenie, A., R. Camerlynck, M. verloo, and A. Dhaese (1980). Fractionation and determination of trace elements in plants, soil and sediments. Pure and Applied Chem ., 52 (1): 45-53.

ESRI (Environmental System Reseach Institute) (2008). ArcGIS 10.1 desktop software help.

FAO (2001).Soil Fertrlity management in support of food security in sub Saharan Africa. Food and agriculture organization of the united nations, Rome, Italy.

Gamma Design Software, (2008) GS+ Geostatistics for the Environmental Sciences, version 9.0, Professional Edition .Plainwell,MI.

Haung, J., R. Haung, J.J.Jiao and K. Chen (2007). Speciation and mobility of heavy metals in mud, in coastal reclamation areasin chenzhen, china, Environment Geology,53(1): 221-228.

Howari,E.M. and K. M. Banat (2001). Assessment of Fe, Zn, Cd. Hg. And Pb in the Jordan and yarmouk River sediments in relation to their physicochemical properties and sequential extraction characterization. Water, Air and Soil pollution, 132 (1-2): 43-59.

Jones, L.H. and S.C. Jarvis (1981). The fate of Heavy metals in the chemistry of soil processes, D.J. Greenlad and M.H.B. Hayes, Eds., PP. 593-620, wiley, New York, Ny, U.S.A

Kabata-Pendias, A., H.Pendias (2001). Trace elements in soils and plants. CRC Press. Boca Raton, Florida, USA; 3rd edition.

Kabala, C. and B.R. Singh (2001). Fractionation and mobility of copper, lead and zinc in soil profiles in the vicinity of a copper smelter. Journal of Environmental Quality, 30: 485-492.

Ma, L. Q. and G.N. Rao (1997). Chemical fractionation of cadmium, copper, nickel, and zinc in contaminated soils Journal of Environmental Quality, 26 (1): 259264.

Nelson. A and P. Donkin (1985).Processes of bioaccumulation: the importance of chemical speciation, Marine Pollution bulletin, 16 (4): $164-169$. 
Oluwatosin,G.A.,O.D.Adeyolanu,T.O.Dauda and G.E.Akinbola (2008). Levels and geochemical fractions of $\mathrm{Cd}, \mathrm{Pb}$,and $\mathrm{Zn}$ in valley bottom soils of some urban cities in South-Western Nigeria.African of Biotechi, 7(19):3455-3465.

Page, A., R. H. Miller, and R. Keeny (1982). Methods of Soil Analysis. Part 2. Chemical and Microbiological properties. SSA.Madiscn, Wiscmsm

Poulton, D., K. J. Simpson, D.R. Barton, and K.R. Lum (1988). Trace metals and benthic invertebrates in sediments of hear shore lakes on tario and Hamilton harbour. J. Great lakes, Res, 14 (1): 52-65.

Quevauviller,P., H.A. Vander Sloot, A. Ure, H. Muntau, A. Gomez, and G. Rauret (1996). Conclusions of the work shop: Harmozation of leaching lextraction tests for environmental risk assessment, Sci Total Environ, 179. (2): 133-139.

Ramirez, M., S. Massolo, R. Frache, and J. a. Correa (2005). Metal Speciation and environmental impact on sandy beaches due to El Salvador copper Mine chile, Marine Pollution Bulletin, 50 (1) : 62-72.

Ratuzny, T., Z. Gong and B.M. Wilke (2009).Total concentrations and speciation of heavy metals in soils of the Shenyang - zhangshi irrigation area, china, Environmental Monitoring and Assessment, 156 (1) : 171-180.

Ryan,P.C., S.H. Hillier, and A. J. Wall (2008). Stepwise effects of the BCR Sequential chemical extraction procedure on dissolution and metal release from common ferromagnesian clay minerals: a combined solution chemistry and X-Ray powder diffraction study. Sci of the Total environ, 407 (1): 603 614.

Shibusawa, S (1998). Precision Farming and terra Mechanics. Processing of the $5^{\text {th }}$ Is Tvs Asia pacific Regional conference, Oct. 20-32 Korea PP: 1008

Tack, F.M.G. and M.F. Verloo (1995). Chemical speciation and fractionation in soil and sediment Heavy metal analysis: a review. Internati Environ. Analytical Chem., 59: (2): 225-238.

Tan,K.H. (1996). Soil sampling, Preparation, and Analysis. Marcel Dekker, Inc., Madison Avenue, New York.

Tessier, A., P.G.C. Campbell and M. Bisson (1979). Sequential extraction procedure for the speciation of particulate trace meals. Analytical Chem., 51: 844-850.

Tessier. A, P.G.C. Campbell, and M. Bisson (1980) . Trace metal speciation in the yamaska and St., Francois Rivers (Quebec). Can. J. Earth Sci., 17: 90105.

Torri, S.I. and R.S. Lavado (2008). Dynamics of $\mathrm{Cd}$, $\mathrm{Cu}$, and $\mathrm{Pb}$ added to soil through different kinds of sewage sludge. Waste Management, 28 (5): 821 832.

Usero, J., M .Gamero, J. Morillo, and I. Gracia (1998). Comparative study of three sequential extraction procedures for metals in marine sediments. Environment Internati., 24 (4): 487-496.

Yehia,H.A.,Y.K.EIGhonamey and A.S.A.Elshemy (2014). Application of Geographic Information System Using ALES-ARID Module for Land 
Evaluation Assessment of Abis area,WestDelta,Egypt .Soil Salinity and Alkalinity Research Lab,Soil,Water and Environment Research institute (SWERI), Giza.J.Agric. Res., 39 (2): 831-851.

Yusuf, K.A. (2007). Sequential extraction of lead, Copper, Cadmium and Zinc in Soils near Ojota waste site. Agroni., 6 (2): 331-337.

Zerbe,J., T.Sobczynski, H. Elbanowska, and J. Siepak (1999). Speciation of heavy metals in bottom sediments of lakes. Polish Environi Studies, 8 (5):331-339.

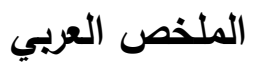

\section{توصيف وحركة الرصاص و الكروم والزنك في أراضي منطقة (بيس - مصر}

'حنان احميدو علاق، ‘ ماهر نسيم، "أيهاب مرسى، “ماجدة أبو المجد و ْهدى عبد القتاح

$$
\text { ' مركز البحوث النطبيقية والتطوير - طرابلس - ليبيا }
$$

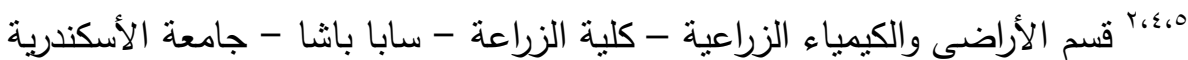

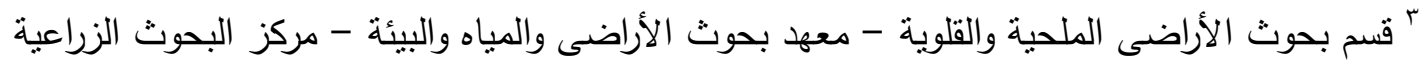

توضح هذه الدراسة التوصيف الكيميائي لكل من الرصاص، الكروم والزنك في أراضي منطقة أبيس في مصر . وتقع منطقة الدراسة في الجزء الثمالي الغربي من دلتا النيل، التي تمنل التربة الناشئة من الرواسب البحيرية في منطقة أبيس

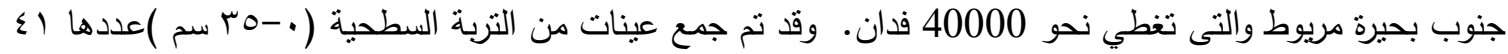
عينة من هذه المساحة لتحليلها واجراء التجارب المعملية عليها. وتم تقدير المحتوى الكلى وصور كل من الرصاص،

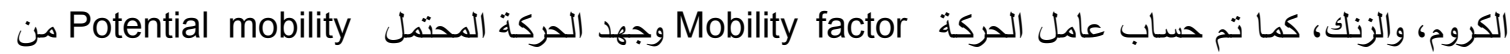
صور هذه العناصر وقد لوحظ انفراد كميات صغيرة من الصور الذائبة والمتبادلة وهى المتاحة للدورات البيولوجية الكيميائية في النظام البيئي ـ و ينواجد الزنك بكميات ضئيلة وأقل من تلك التي من الرصاص أو الكروم. وانخفاض

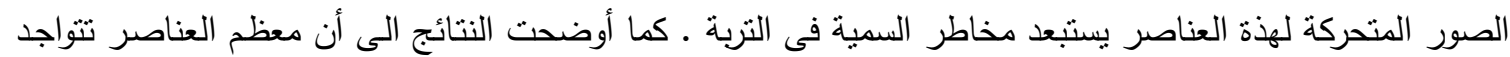

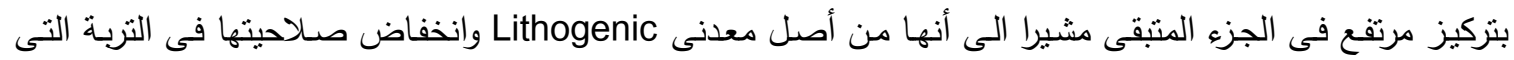
شملتها الدراسة.و كان منوسط قيم عامل الحركة لكل من الرصاص، الكروم والزنك في هذه الأراضي من منطقة أبيس

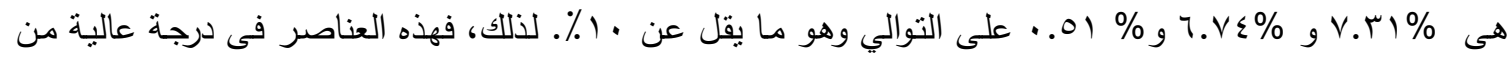

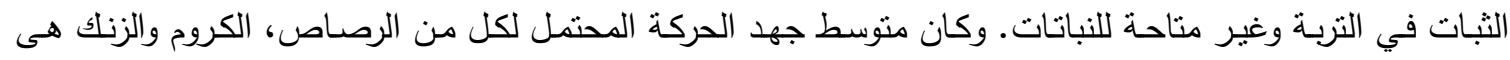

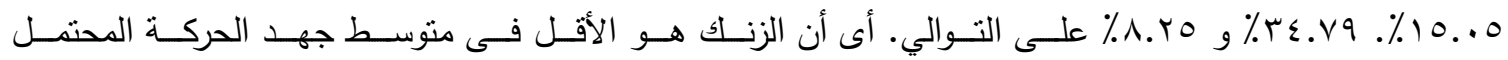

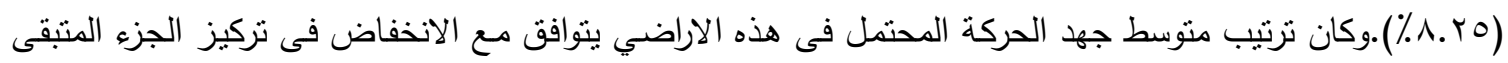

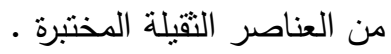

